\title{
Monitoring of external predisposing factors for Diabetic Foot: A literature review and physicians' perspectives
}

\author{
Khadijeh Moulaei ${ }^{1}$, Mojtaba Malek ${ }^{2}$, Abbas Sheikhtaheri*3
}

Received: 21 Nov 2018

Published: 31 Dec 2019

\begin{abstract}
Background: Diabetic foot is one of the most important complications of diabetes caused by the existence of some destructive factors in different anatomical locations of feet. Management and monitoring of these factors are very important to decrease or avoid ulcerating lesions of the foot. The purpose of this study is to identify and introduce the predisposing factors and anatomical locations associated with these destructive factors.

Methods: First, we conducted a comprehensive review of different databases to identify the factors and associated anatomical locations from the previous studies. Then, we designed a questionnaire and invited physicians and specialists to express their perspectives on these factors and locations. The data were analyzed using SPSS version 23. Frequency, percentage, mean and standard deviation of these variables were calculated.

Results: Based on the literature review, four factors, including pressure, moisture and sweat, temperature, and acceleration were identified as factors destructive to the tissues of the diabetic foot and worsen ulcers. The view of specialists approved the results of the literature review. Besides, there was an insignificant difference between the results of the literature review and the specialists' view in terms of anatomical locations that need to be continuously monitored.

Conclusion: Monitoring the pressure in heel, first metatarsal, and first metatarsal head; moisture and sweat under the fingers, hallux and heels as well as the temperature at the first metatarsal, first metatarsal head, and the third metatarsal head are important in preventing ulceration, destructing the foot tissue, and accelerating the treatment process.
\end{abstract}

Keywords: Diabetic foot, Monitoring, Factors, Foot ulcer

Conflicts of Interest: None declared

Funding: This study was supported by Iran University of Medical Sciences (Code: 96-04-136-32532).

*This work has been published under CC BY-NC-SA 1.0 license.

Copyright $\odot$ Iran University of Medical Sciences

Cite this article as: Moulaei Kh, Malek M, Sheikhtaheri A. Monitoring of external predisposing factors for Diabetic Foot: A literature review and physicians' perspectives. Med J Islam Repub Iran. 2019 (31 Dec);33:159. https://doi.org/10.47176/mjiri.33.159

\section{Introduction}

One of the most important complications of diabetes is diabetic foot, by which about 15 to 25 percent of diabetics are affected (1). According to the World Health Organization, diabetic foot is defined as infection, ulceration, or destruction of the deep soft tissues associated with neurological abnormalities and peripheral vascular involvement in the lower limbs (2). Every 20 seconds, one foot in the world is amputated due to diabetes although more than 80 percent of these cases are preventable (3). Foot ulcer is the most important affecting factor for infection in diabetic

\section{Corresponding author:Dr Abbas Sheikhtaheri, sheikhtaheri.a@iums.ac.ir}

1. School of Health Management and Information Sciences, Iran University of Medical Sciences, Tehran, Iran

2. Research Center for Prevention of Cardiovascular Disease, Institute of Endocrinology and Metabolism, Iran University of medical sciences, Tehran, Iran

3. Health Management and Economics Research Center, Department of Health Information Management, School of Health Management and Information Sciences, Iran University of Medical Sciences, Tehran, Iran patients (4). Therefore, without providing the necessary care, these ulcers can lead to infection, gangrene, amputation and even death (5).

One of the most common causes of diabetic foot ulcers is neuropathy. Neuropathy leads to the absence of sensation or deformation of the foot. In this group of patients, even a small trauma may lead to a chronic ulcer. Furthermore, continuous walking on the injured foot with the absence of the sense of pain and pressure lead to failure in the treatment process because with the presence of periph-

$\uparrow$ What is “already known" in this topic:

Many parameters related to foot and footwear may result in or exacerbate foot ulcers in patients with diabetes.

\section{$\rightarrow$ What this article adds:}

In order to prevent the formation of wounds in the diabetic foot, the parameters that cause diabetic foot ulcers, such as pressure, temperature, and humidity should be monitored, measured and managed. 
eral vascular disease, ulcers will develop to an ischemic ulcer and a non-improved wound (6). In addition to this internal factor, many external factors related to the foot and shoes such as pressure, temperature, humidity, foot movement in shoes, shoe straps, insoles, depth and stiffness of shoes can increase the diabetic ulcers. Each of these external aspects requires the patient's attention to monitor the condition of the wound (7).

It has been shown that preventive actions have a positive impact on the quality of patients' lives and reduce healthcare costs (8). Therefore, the primary advice for preventing diabetic foot ulcers is daily inspection and continuous monitoring of foot, temperature control and orthotic shoes (9). In order to prevent the formation of wounds in the foot, the parameters that cause diabetic foot ulcers, such as pressure, temperature, and humidity should be monitored, measured and managed (10).

Diabetic foot problems have been presented as the main cause of illness, disability, and mortality in diabetic patients (11). Although different studies have been conducted to identify and introduce the influential factors, no comprehensive review has been done to investigate the mentioned parameters and important anatomical locations for monitoring these factors. Therefore, the aim of this study is to identify external factors that may result in forming and deteriorating the diabetic foot and major anatomical locations of this problem.

\section{Methods}

The study was conducted in the two following phases

\section{A comprehensive review of the literature}

A comprehensive review of the literature was conducted to identify the external factors and the anatomical locations for monitoring these factors. PubMed/Medline, Web of Science, ProQuest, Scopus, Google Scholar, Science Direct, and Springer web sites were searched. The search process was performed using Medical Subject Headings (Mesh) terms and the synonyms. The articles published between January 2005 and October 2017 were searched. Published articles in scientific conferences and journals were selected. A sample of the search strategy in Pub$\mathrm{med} /$ Medline is given in Table 1 . We customized this strategy for other databases.

At first, the titles and abstracts of the retrieved papers were screened. Next, based on the inclusion and exclusion criteria, the articles were selected. Then, fulltexts of the articles were studied; and the name of the factors and anatomical locations were extracted. The data were collected using a data extraction form.

The inclusion criteria were as follows: articles published in English, access to the fulltexts of the articles, and data on the factors affecting foot ulcer. Exclusion criteria were as follows: articles addressing other aspects of diabetes and diabetic foot, non-English papers, books, book chapters, letters to the editor, and the abstract of the conferences.

2. Investigating specialists' point of view regarding the important factors

At this phase, a questionnaire was developed to collect the data. Endocrinologists and physical medicine specialists were asked regarding the possible important factors and related anatomical locations. The questionnaires were distributed among physicians and then collected after several days.

The questionnaire consisted of two parts. The first part included the specialists' demographic data, and the second part included the questions related to the factors and anatomical locations in the form of five-point Likert scale. Five questions were developed to be asked about the importance of factors and 26 and 13 questions regarding the anatomical locations for monitoring pressure and temperature, respectively. Moreover, open questions were used to identify the major anatomical locations for monitoring the foot's moisture, sweat, and acceleration.

Face and content validity of the questionnaire were confirmed by two physical medicine specialists and endocrinologists. Based on the received opinions, some anatomical locations were removed from the questionnaire. Validity of the questionnaire was analyzed using Cronbach's Alpha (0.934).

In this study, all physical medicine specialists and endocrinologists affiliated to Iran University of Medical Sciences ( 24 specialists) were invited to study, and finally, 19 questionnaires were completed and analyzed. In order to analyze the data, each factor and anatomical sites were scored from 1 to 5 (very low important to very important). Then the frequency, percentage, mean and standard deviation were calculated. All analyses were conducted in SPSS 23.

\section{Results}

The frequency of female participants was higher than males. The majority of participants were 45 to 55 years old. Most of them had 1 to 10 years of experience (57.9 percent) (Table 2).

Regarding the literature review, abstracts and titles of 600 retrieved papers were screened. After removing the duplicates and irrelevant studies and considering the inclusion and exclusion criteria, 100 studies were included in the analysis (Table 3).

According to the review, plantar pressure with 78 references (12-89), moisture and sweat with 29 references $(27$, $28,34,51-55,57,58,72-75,78,81,83,86,87,90-99)$, foot temperature with 27 references $(28,34,51-55,57,58$, $72-76,78,81,82,87,100-108)$ and acceleration on foot with 5 references $(28,82,109-111)$ were the most

\begin{tabular}{ll} 
Table 1. Keywords and search strategy \\
\hline Row & Keywords \\
\hline 1 & (Diabetic foot OR diabetic feet OR diabetic neuropathies OR foot ulcer* OR planter ulcer) \\
2 & (Risk factor OR high risk OR foot biomechanics OR foot fissures) \\
3 & (Plantar* OR peak pressure OR pressure* OR moisture* OR temperature* OR heat OR \\
& sweat OR friction OR accelerate OR force OR high-heeled OR force transducer) \\
Search strategy & [(1) AND (2) AND (3)]
\end{tabular}




\begin{tabular}{|c|c|c|c|}
\hline Variables & & Frequency & Percentage \\
\hline \multirow[t]{2}{*}{ Sex } & Male & 7 & 36.8 \\
\hline & Female & 12 & 63.2 \\
\hline \multirow[t]{5}{*}{ Age } & $25-35$ & 4 & 21.1 \\
\hline & $36-45$ & 4 & 21.1 \\
\hline & $46-55$ & 7 & 36.8 \\
\hline & $>55$ & 1 & 5.3 \\
\hline & No response & 3 & 15.8 \\
\hline \multirow[t]{2}{*}{ Education degree } & Specialist & 9 & 47.4 \\
\hline & Sub-specialist & 10 & 52.6 \\
\hline \multirow[t]{3}{*}{ Type of medical Specialties } & Endocrinologist & 13 & 68.4 \\
\hline & Physical medicine & 6 & 31.6 \\
\hline & $1-10$ & 11 & 57.9 \\
\hline \multirow[t]{2}{*}{ Years of service } & $11-21$ & 3 & 15.8 \\
\hline & $>21$ & 5 & 26.3 \\
\hline
\end{tabular}

frequently cited factors, respectively (Table 3).

Moreover, according to Table 3, from the specialists' points of view, pressure, moisture and sweat, temperature, and acceleration are important to be monitored, respectively. Only three participants suggested other factors such as foot size, foot shape, muscle strength, color, foot ulcers (each of these have been mentioned once).

Based on the review of the literature, heel, first metatarsal head, fifth metatarsal head, hallux, and first metatarsal bone were identified as the five anatomical locations need to be monitored for pressure. Besides, five anatomical locations including first metatarsal bone, first metatarsal head, third metatarsal head, fifth metatarsal head, and the middle of the foot were identified as the most important locations that should be monitored for temperature. It should be noted that regarding moisture and sweat as well as acceleration, the selected papers had not introduced any certain anatomical location (Table 4). According to the findings (Table 4), five locations including first finger, first metatarsal head, heel, first metatarsal and third metatarsal head were prioritized to be monitored for pressure (mean $\geq 4$ ). Additionally, according to the specialists'

Table 3. Required factors for monitoring the diabetic foot based on literature review and specialists' perspectives

\begin{tabular}{|c|c|c|c|c|c|c|c|c|}
\hline \multicolumn{3}{|c|}{ Results of literature review } & \multicolumn{6}{|c|}{ Specialists' perspectives } \\
\hline \multirow[b]{2}{*}{ Factors } & \multirow[b]{2}{*}{$\begin{array}{l}\text { Number of } \\
\text { References }\end{array}$} & \multirow[b]{2}{*}{ References } & \multicolumn{5}{|c|}{ Frequency (percentage) } & \multirow[t]{2}{*}{ Mean \pm SD } \\
\hline & & & $\begin{array}{c}\text { Very } \\
\text { important }\end{array}$ & Important & $\begin{array}{l}\text { Moderate } \\
\text { important }\end{array}$ & $\begin{array}{c}\text { Low } \\
\text { important }\end{array}$ & $\begin{array}{l}\text { Very low } \\
\text { important }\end{array}$ & \\
\hline Foot pressure & 78 & $(12-89)$ & $\begin{array}{c}14 \\
(73.7)\end{array}$ & $\begin{array}{c}2 \\
(10.5)\end{array}$ & $\begin{array}{c}3 \\
(15.8)\end{array}$ & $\begin{array}{c}0 \\
(0)\end{array}$ & $\begin{array}{c}0 \\
(0)\end{array}$ & $4.58 \pm 0.76$ \\
\hline Moisture & 29 & $\begin{array}{c}(27,28,34,51-55,57, \\
58,72-75,78,81,83,86, \\
87,90-99)\end{array}$ & $\begin{array}{c}6 \\
(31.6)\end{array}$ & $\begin{array}{c}8 \\
(42.1)\end{array}$ & $\begin{array}{c}4 \\
(1.21)\end{array}$ & $\begin{array}{c}1 \\
(5.3)\end{array}$ & $\begin{array}{c}0 \\
(0)\end{array}$ & $4.00 \pm 0.88$ \\
\hline $\begin{array}{l}\text { Foot } \\
\text { temperature }\end{array}$ & 27 & $\begin{array}{c}(28,34,51-55,57,58 \\
72-76,78,81,82,87 \\
100-108)\end{array}$ & $\begin{array}{c}8 \\
(42.1)\end{array}$ & $\begin{array}{c}8 \\
(42.1)\end{array}$ & $\begin{array}{c}3 \\
(15.8)\end{array}$ & $\begin{array}{c}0 \\
(0)\end{array}$ & $\begin{array}{c}0 \\
(0)\end{array}$ & $4.26 \pm 0.73$ \\
\hline Acceleration & 5 & $(28,82,109-111)$ & $\begin{array}{c}5 \\
(26.3)\end{array}$ & $\begin{array}{c}5 \\
(26.3) \\
\end{array}$ & $\begin{array}{c}4 \\
(21.1) \\
\end{array}$ & $\begin{array}{c}3 \\
(15.8) \\
\end{array}$ & $\begin{array}{c}2 \\
(10.5)\end{array}$ & $3.42 \pm 1.34$ \\
\hline
\end{tabular}

Table 4. Anatomical locations for monitoring foot pressure based on literature review and specialists' perspectives

\begin{tabular}{|c|c|c|c|}
\hline \multicolumn{3}{|c|}{ Results of the literature review } & \multirow{2}{*}{$\begin{array}{c}\text { Specialists' perspectives } \\
\text { Mean } \pm \text { SD }\end{array}$} \\
\hline Anatomical locations & Number of references & References & \\
\hline Heel & 23 & $(19-23,26,33,34,36-39,41,49,50,80,85,86,112)$ & $4.47 \pm 0.69$ \\
\hline First metatarsal head & 17 & $(20-22,25,32,36,39,42,47,49,50,77-80,82,86)$ & $4.68 \pm 0.67$ \\
\hline Fifth metatarsal head & 16 & $(19,20-22,25,32,35,36,39,42,49,50,77-79,113)$ & $4.00 \pm 0.81$ \\
\hline Hallux & 15 & $(15,18,23,26,29,30,37,40,42,43,78,79,85,86,89,113)$ & $4.06 \pm 0.69$ \\
\hline First metatarsal & 14 & $(12,13,15,23,26-28,38,40,43,46,87,89)$ & $4.22 \pm 1.00$ \\
\hline Third metatarsal head & 13 & $(19-22,25,32,36,39,47,50,79,80,82)$ & $4.11 \pm 0.73$ \\
\hline Second metatarsal Head & 12 & $(20-22,25,32,36,39,47,48,51,77)$ & $4.26 \pm 1.04$ \\
\hline Fourth metatarsal head & 11 & $(19-22,25,32,36,39,77,78,86)$ & $3.84 \pm 1.01$ \\
\hline Second metatarsal & 10 & $(13,15,18,23,26,40,51,77,87,89)$ & $3.88 \pm 0.99$ \\
\hline Fifth metatarsal & 9 & $(13,26,28,38,45,49,80,87,89)$ & $3.44 \pm 0.89$ \\
\hline First finger & 8 & $(19,28,34,48,77,82,86,87)$ & $4.74 \pm 0.56$ \\
\hline Fourth metatarsal & 5 & $(15,18,26,47,89)$ & $3.41 \pm 0.71$ \\
\hline Third metatarsal & 4 & $(12,18,45,89)$ & $3.47 \pm 0.71$ \\
\hline Toe & 3 & $(26,36,42)$ & $3.77 \pm 0.77$ \\
\hline Third finger & 3 & $(79,82,87)$ & $3.44 \pm 0.89$ \\
\hline Calcaneus & 3 & $(24,25,25)$ & $3.47 \pm 1.12$ \\
\hline Fifth Finger & 2 & $(30,79)$ & $3.44 \pm 0.89$ \\
\hline Lateral Mid-foot & 2 & $(26,34)$ & $3.35 \pm 0.66$ \\
\hline Mid-foot & 1 & $(87)$ & $2.76 \pm 3.35$ \\
\hline Fourth finger & 1 & (85) & $3.24 \pm 0.66$ \\
\hline Second finger & 1 & (19) & $3.88 \pm 0.99$ \\
\hline
\end{tabular}




\begin{tabular}{|c|c|c|c|c|}
\hline \multicolumn{3}{|c|}{ Results of the literature review } & \multicolumn{2}{|c|}{ Specialists' perspectives } \\
\hline Anatomical locations & Number of references & References & $\mathrm{Me}$ & $\mathrm{SD}$ \\
\hline Instep & 1 & $(23)$ & & 1.14 \\
\hline Navicular & 1 & (19) & 2.9 & 0.82 \\
\hline Medial forefoot & 5 & $(31,34,48,77,78)$ & * & $*$ \\
\hline Under the metatarses & 2 & $(14,44)$ & $*$ & $*$ \\
\hline Lateral forefoot & 3 & $(30,31,34)$ & $*$ & $*$ \\
\hline Central forefoot & 2 & $(30,31)$ & $*$ & $*$ \\
\hline Metatarsal joints and Falangular Joint first & 2 & $(35,85)$ & $*$ & $*$ \\
\hline Fifth metatarsal phalangeal joint & 2 & $(35,85)$ & $*$ & $*$ \\
\hline Proximal inter phalangeal & 1 & $(35)$ & $*$ & $*$ \\
\hline
\end{tabular}

*These locations were removed from the questionnaire because of the specialists' views on the content validity of the questionnaire.

Table 5. Anatomical locations for monitoring foot temperature based on literature review and specialists' perspectives

\begin{tabular}{lccc}
\hline Anatomical locations & Number of References & References & Mean \pm SD \\
\hline First metatarsal & 5 & $(28,67,102,106,107)$ & $3.75 \pm 1.00$ \\
First metatarsal head & 4 & $(100-102,105)$ & $3.67 \pm 1.04$ \\
Third metatarsal head & 4 & $(100-102,105)$ & $3.20 \pm 0.94$ \\
Fifth metatarsal head & 4 & $(79,101,102,105)$ & $3.21 \pm 0.97$ \\
Medial mid-foot & 4 & $(100-102)$ & $3.56 \pm 1.15$ \\
Heel & 3 & $(100-102)$ & $3.69 \pm 1.25$ \\
First finger & 3 & $(28,100,101)$ & $4.00 \pm 1.02$ \\
Calcaneus & 2 & $(28,80)$ & $3.13 \pm 0.99$ \\
Fifth metatarsal & 1 & $(28)$ & $3.25 \pm 1.00$ \\
Fourth metatarsal head & 1 & $(100)$ & $3.13 \pm 0.99$ \\
Hallux & 1 & $(105)$ & $3.40 \pm 1.12$ \\
Cuboid & 1 & $(105)$ & $2.93 \pm 1.03$ \\
Cuneiform & 1 & $(105)$ & $2.80 \pm 0.86$ \\
\hline
\end{tabular}

views, five locations including first finger, first metatarsal, heel, first metatarsal head and medial mid-foot were the most important locations to be monitored for temperature (Table 5).

Regarding the mentioned anatomical locations to be monitored for moisture and sweat, only a limited number of participants answered the open question related to this factor. They mentioned these locations: under fingers, in the fingers, and heels (seven people for each), the exterior part of the foot (six people), middle part of the foot front and the central part of the foot front (three people), hallux (two people), first metatarsal bone, first metatarsal head, second metatarsal head, third metatarsal head, on the foot and ankles (one people for each).

The specialists also considered heel (ten people), first metatarsal head (seven people), second metatarsal head, third metatarsal head (six people for each), fourth metatarsal head, fifth metatarsal head and the toes (five people), hallux (three people), first metatarsal, cuboid and navicular (two people for each), toe, Mid-foot, calcaneus and instep (one people for each) as important location to be monitored for acceleration.

\section{Discussion}

We found that pressure, moisture and sweat, temperature and acceleration are important, and among them, the pressure is more important than the other factors to be monitored. Payne et al. presented the plantar pressure as the major non-traumatic mechanical risk for the diabetic foot (114). Pham et al. and La salvia et al. also showed that there is a direct relationship between foot ulcer and increased topical pressure in a way that ulcer is initiated as a result of undesirable pressure and then it will lead to break the protective layers of the skin and in turn result in an ulcer $(115,116)$.
According to the above-mentioned discussion, two questions are posed: 1 . Why are the pressure and moisture more important than the temperature? 2. Why are moisture and sweat necessary and essential for the diabetic foot, unlike the temperature and pressure?

In response to the first question, Payne et al. study can be considered. They presented the local increase of the plantar pressure as the major non-traumatic mechanical risk for the diabetic foot (114). Moreover, Brand reported that the pressure might cause an increase in temperature, destruction of the texture, and ulcer (117). Hall et al. also reported that a six-minute walk could result in a $5{ }^{\circ} \mathrm{C}$ increase in the temperature. Therefore, the temperature of the plantar can be increased as a result of forces or mechanical pressures in plantar (118). Shah mentioned that principles for treating diabetic foot are changing in nutrition, blood glucose and infection control, effective debridement, dressing and maintaining the ulcer moisture and sweat and eliminating the foot pressure, but he did not consider the temperature in the treatment principles (119). According to Bolton et al., the treatment of the foot ulcer consists of two phases: first, the exact diagnosis of the ulcer and the damaged tissue, and second, detailed assessment of ulcer in which following processes should be provided: cleaning, pain-reduction, removing necrotic tissue and adding moisture to dry ulcer and managing the excessive moisture and sweat (120).

Similar to the Shah's study, Bolton et al. considered the moisture and perspiration as a principle in the treatment of the foot ulcers and focused on its control to improve the foot ulcers. In addition, Volmer et al. declare that sweat secretion as a result of autonomic neuropathy increases blood perfusion from the deep layer and leads to the skin overheat (121).

Therefore, according to the previous statements, it can 
be declared that temperature cannot be denied as a parameter to monitor the diabetic foot. However, similar to the findings in the review of the literature and specialists' view, in order to monitor the diabetic foot, pressure, moisture and perspiration should be in a higher priority than temperature, but the temperature cannot be ignored.

In response to the second question, it is necessary to remind that the foot skin will be dry because of inadequate perspiration and moisture. Therefore, the protective function of the skin will be fragile, and the damage risk will increase, and because of autonomic neuropathy, conditions such as arterial sclerosis, Charcot foot, neuropathic edemas, and other changes will happen (121). There are several hypotheses for emphasizing on the moisture and perspiration to the extent necessary to improve the diabetic foot ulcers. Landsman et al. have recognized excessive wetness or moisture as a cause of separating and destructing the tissue levels, spreading infection and turning it into a deep ulcer (98). Accordingly, it can be argued that both little and excessive moisture and perspiration will increase the risk of forming and worsening the diabetic foot ulcers; therefore, its amount should be considered and monitored.

The findings derived from the literature and specialists' perspectives showed that monitoring the pressure of the first finger, the first metatarsal head, the heel, the first metatarsal, the third metatarsal head, the fifth metatarsal head and the hallux is significant to prevent the ulcerating, tissue destructing and accelerate the treatment process in this group of patients. Singh et al. and Lavery et al. believe that the pressure peak occurs in the heel, metatarsals, and first fingers in diabetic patients $(52,122)$. The reason of increased pressure in the metatarsal head is found at the phase of the pressing on the foot when the heel come apart from the ground, and the whole body weight is on the front part of the foot and in this case, the heel and the midfoot cannot bear extra body weight, but the pressure of the metatarsal heads may increase to 414 kilopascal (123).

Although some participants in the study emphasized on monitoring the moisture and perspiration in some specific locations of the foot, based on the review of the literature, certain anatomical locations were not found. Landsman et al. also believe that the moisture and perspiration are not related to a certain point of anatomical location on the foot, but it usually can be seen more around the ulcer (98). Coates et al. also did not present a certain anatomical location to monitor the foot perspiration and moisture (28).

Based on the review of the literature, five anatomical locations including the first metatarsal, the first metatarsal head, the third metatarsal head, the fifth metatarsal head and middle of the foot to monitor the temperature has been more introduced. Moreover, specialists emphasized on the first finger, first metatarsal, heel, the first metatarsal head and the medial mid-foot for monitoring the plantar temperature. Enkhzul et al. considered the toe, the first metatarsal head, the third metatarsal head, the fourth metatarsal head, the middle of foot, and heels to monitor the foot temperature (100). Coates et al. also suggested calcaneus, the first metatarsal and first finger to be monitored for temperature (28). Bus et al. believe that increasing the local temperature can occur in the interior medial of the left foot and under the first metatarsal head area in the right foot. They also declared that increasing local temperature is a warning sign to destruct the skin in the future (67). Erdenechimeg also suggested that the first metatarsal head, the third metatarsal head, the fifth metatarsal head, the toe, interior of the mid-foot and the heel should be monitored in terms of the temperature (101).

This study has some limitations. First, the specialists in one of the medical sciences universities in Iran were surveyed; therefore, the results cannot be generalized to the whole specialists in the country. Second, although we invited all of the specialists, most of the participants had less than 10 years of experience. However, we think that this did not affect our study because their viewpoints are in line with the literature. Third, the first phase of the study is not a systematic review. Forth, we aimed to identify the factors and related anatomical locations. Therefore, all types of studies with different methods were included. It is clear that the quality of all studies is not at the same level and finally, in this study, we considered only the external factors related to diabetic foot, and we did not consider other factors such as neuropathy.

\section{Conclusion}

According to the findings, we can conclude that among the destructive parameters, monitoring the pressure and temperature considering the related anatomical locations is very important to prevent ulcerating, destructing the foot tissue and accelerating the process of the treatment for this group of patients. Monitoring the pressure in the first finger, the first metatarsal head, the heel, the first metatarsal, the third metatarsal head, the fifth metatarsal head and the hallux as well as monitoring the temperature in the first finger, the first metatarsal, the first metatarsal head, the third metatarsal head, the fifth metatarsal head, the heel and middle of the foot are more important than other anatomical locations. The results of this study can be considered as a base to formulate and develop educational programs aimed to enhance the diabetics foot care, pave the ways to identify the foot problems in patients immediately and decrease the diabetic foot complications in patients with increased knowledge and the self-management performance of this group of patients.

\section{Acknowledgments}

This study was supported by Iran University of Medical Sciences (Code: 96-04-136-32532).

\section{Ethical Consideration}

This study was approved by research ethics committee of Iran University of Medical Sciences (IR.IUMS.REC.1396.32532).

\section{Conflict of Interests}

The authors declare that they have no competing interests.

\section{References}

1.Naemi R, Chatzistergos P, Suresh S, Sundar L, Chockalingam N, 
Ramachandran A. Can plantar soft tissue mechanics enhance prognosis of diabetic foot ulcer? Diabetes Res Clin Pract. 2017;126:182-91.

2.Aalaa M, Malazy OT, Sanjari M, Peimani M, Mohajeri-Tehrani M. Nurses' role in diabetic foot prevention and care; a review. J Diabetes Metab Disord. 2012;11(1):2-6.

3.Macioch T, Sobol E, Krakowiecki A, Mrozikiewicz-Rakowska B, Kasprowicz M, Hermanowski T. Health related quality of life in patients with diabetic foot ulceration-translation and Polish adaptation of Diabetic Foot Ulcer Scale short form. Health Qual Life Outcomes. 2017;15(1):2-8

4.Lipsky BA, Berendt AR, Deery HG, Embil JM, Joseph WS, Karchmer AW, et al. Diagnosis and treatment of diabetic foot infections. Plast Reconstr Surg. 2006;117(7 Suppl):212s-38s.

5.Snyder RJ, Hanft JR. Diabetic foot ulcers--effects on QOL, costs, and mortality and the role of standard wound care and advanced-care therapies. Ostomy Wound Manage. 2009;55(11):28-38.

6.Iraj B, Khorvash F, Ebneshahidi A, Askari G. Prevention of Diabetic Foot Ulcer. J Prev Med. 2013;4(3):373-6.

7.Germani M, Mandolini M, Mengoni M, Raffaeli R, Montiel E, Davia M. Methods and tools dedicated to shoes customization for people with diabetes. International conference on Innovative Methods in Product Design. Italy, Venice; 15-11 June 2011.p.115-6.

8.Hellstrand Tang U, Zügner R, Lisovskaja V, Karlsson J, Hagberg K, Tranberg R. Comparison of plantar pressure in three types of insole given to patients with diabetes at risk of developing foot ulcers - A two-year, randomized trial. J Clin Transl Endocrinol. 2014;1(4):12132

9.Lott DJ, Hastings MK, Commean PK, Smith KE, Mueller MJ. Effect of footwear and orthotic devices on stress reduction and soft tissue strain of the neuropathic foot. Clin Biomech (Bristol, Avon). 2007;22(3):352-9.

10. Abidoye A. Using wearable sensors for remote healthcare monitoring system. J Sens Technol.2011; 01(02):22-28.

11. Andersen CA, Roukis TS. The diabetic foot. Surg Clin North Am. 2007;87(5):1149-77.

12. Van Schie CM. A review of the biomechanics of the diabetic foot. Int J Low Extrem Wounds. 2005;4(3):160-70.

13. Amemiya A, Noguchi H, Oe M, Takehara K, Ohashi Y, Suzuki R, et al. Shear Stress-Normal Stress (Pressure) Ratio Decides Forming Callus in Patients with Diabetic Neuropathy. J Diabetes Res. 2016;2016; 1-10.

14. Actis RL, Ventura LB, Smith KE, Commean PK, Lott DJ, Pilgram TK, et al. Numerical simulation of the plantar pressure distribution in the diabetic foot during the push-off stance. Med Biol Eng Comput.2006;44(8):653-63.

15. Cong Y, Cheung JTM, Leung AK, Zhang M. Effect of heel height on in-shoe localized triaxial stresses. J Biomech. 2011;44(12):226772 .

16. Mueller MJ, Lott DJ, Hastings MK, Commean PK, Smith KE, Pilgram TK. Efficacy and mechanism of orthotic devices to unload metatarsal heads in people with diabetes and a history of plantar ulcers. Phys Ther. 2006;86(6):833-42.

17. Tuna H, Birtane M, Güldiken S, Soysal NA, Taşpinar Ö, SÜT N, et al. The Effect of Disease Duration on Foot Plantar Pressure Values in Patients with Type 2 Diabetes Mellitus Turk J Phys Med Rehabil. 2014; 14(4), 372-80.

18. Menz HB, Zammit GV, Munteanu SE. Plantar pressures are higher under callused regions of the foot in older people. Clin Exp Dermatol. 2007;32(4):375-80.

19. Öztürk B, Angın E, Güçhan Z, Yurt Y, Malkoç M. Assessment of the Plantar Pressure, Muscle Strength and Balance in Patients with Type 2 Diabetes Mellitus in Cyprus. Open J Endocr Metab Dis. 2016;6(05):151-8.

20. Janisse D, Janisse E. Pedorthic management of the diabetic foot. Prosthet Orthot Int. 2015;39(1):40-7.

21. Luboz V, Perrier A, Stavness I, Lloyd JE, Bucki M, Cannard F, et al. Foot ulcer prevention using biomechanical modelling. Comput Methods Biomech Biomed Eng Imaging Vis. 2014;2(4):189-96.

22. Luboz V, Perrier A, Bucki M, Cannard F, Diot B, Vuillerme N, et al. Dynamic biomechanical modelling for foot ulcer prevention. Comput Methods Biomech Biomed Engin. 2013;16(sup1):149-51.

23. Fernando ME, Crowther RG, Cunningham M, Lazzarini PA, Sangla KS, Golledge J. Lower limb biomechanical characteristics of patients with neuropathic diabetic foot ulcers: the diabetes foot ulcer study protocol. BMC Endocr Disord. 2015;15(1):1-44.

24. Waaijman R, de Haart M, Arts ML, Wever D, Verlouw AJ, Nollet $\mathrm{F}$, et al. Risk factors for plantar foot ulcer recurrence in neuropathic diabetic patients. Diabetes Care. 2014;37(6):1697-705.

25. Bader MS, Brooks A. Medical management of diabetic foot infections. Postgrad Med. 2012;124(2):102-13.

26. Ledoux WR, Shofer JB, Cowley MS, Ahroni JH, Cohen V, Boyko EJ. Diabetic foot ulcer incidence in relation to plantar pressure magnitude and measurement location. J Diabetes Complicat. 2013;27(6):621-6

27. Torkington-Stokes R, Metcalf D, Bowler P. Management of diabetic foot ulcers: evaluation of case studies. Br J Nurs. 2016;25(15):S27S33.

28. Coates J, Chipperfield A, Clough G. Wearable multimodal skin sensing for the diabetic foot. Electronics. 2016;5(3):30-45.

29. AL-Baghdadia JAA, Chongb AK, Milburnc PD. Fabrication and Testing of a Low-cost Foot Pressure Sensing System. Proceedings of the 3rd International Conference on Industrial Application Engineering; Sapporo Japan; 23 March 2015.p. 1-9.

30. Yavuz M. American Society of Biomechanics Award 2012: plantar shear stress distributions in diabetic patients with and without neuropathy. Clin Biomech (Bristol, Avon). 2014;29(2):223-9.

31. Sacco IC, Hamamoto AN, Tonicelli LM, Watari R, Ortega NR, Sartor CD. Abnormalities of plantar pressure distribution in early, intermediate, and late stages of diabetic neuropathy. Gait \& Posture. 2014;40(4):570-4

32. Manikandan K, Kumar L, Sivaraman J, Padmapriya P, Vijayalakshmi C. Design and development of a foot pressure scanner for diabetic patients. Indian J Sci Technol. 2016;9(2).

33. Morère CS, Surażyński Ł, Pérez-Tabernero AR, Vihriälä E, Myllylä T. MEMS technology sensors as a more advantageous technique for measuring foot plantar pressure and balance in humans. J Sens. 2016;2016(4):1-9.

34. Benbakhti AS, Boukhenous S, Zizoua C, Attari M, editors. An instrumented shoe for ambulatory prevention of diabetic foot ulceration. Wireless Mobile Communication and Healthcare (Mobihealth), 2014 EAI 4th International Conference on; Athens, Greece:IEEE;3-5 Nov. 2014. p.1-6.

35. Hurst B, Branthwaite H, Greenhalgh A, Chockalingam N. Medicalgrade footwear: the impact of fit and comfort. J Foot Ankle Res 2017;10(1):2-7.

36. Ostadabbas S, Saeed A, Nourani M, Pompeo M, editors. Sensor architectural tradeoff for diabetic foot ulcer monitoring. Engineering in Medicine and Biology Society (EMBC), 2012 Annual International Conference of the IEEE; San Diego, CA, USA: IEEE; 12 November 2012.p. 6687-90.

37. Ci J, Feng R, Jun LM, Jianshe L. Loading character of diabetic foot in young patients during normal speed walking. J Chem Pharm Res. 2014;6(5):982-4

38. Wahab Y, Mazalan M, Bakar N, Anuar A, Zainol M, Hamzah F, editors. Low power shoe integrated intelligent wireless gait measurement system. J Phys Conf Ser. 2014: 495 (2014): 1-7.

39. Low JH, Khin PM, Yeow CH, editors. A pressure-redistributing insole using soft sensors and actuators. Robotics and Automation (ICRA), 2015 IEEE International Conference on; 2015; Seattle, WA USA: 02 July 2015.p. 2926-30.

40. Takano M, Noguchi H, Oe M, Sanada H, Mori T. Development and evaluation of a system to assess the effect of footwear on the in shoe plantar pressure and shear during gait. ROBOMECH J. 2014;1(1):1-7. 41. Sazonov ES, Bumpus T, Zeigler S, Marocco S, editors. Classification of plantar pressure and heel acceleration patterns using neural networks. International Joint Conference on Neural Networks, IJCNN'05 Proceedings IEEE, Montreal, Que, Canada: IEEE 31 July-4 Aug. 2005.p.1-5.

42. Bus S, Waaijman R, Arts M, Manning H. The efficacy of a removable vacuum-cushioned cast replacement system in reducing plantar forefoot pressures in diabetic patients. Clin Biomech (Bristol, Avon). 2009;24(5):459-64.

43. Jelinek H, Munro J, Tinley P. Dynamic first metatarsophalangeal joint movement in diabetes foot assessment of type 2 diabetic women. J Diabetic Foot Compl. 2010;2(3):51-6.

44. Sawacha Z. Validation of plantar pressure measurements for a novel in-shoe plantar sensory replacement unit. SAGE Publications Sage CA: Los Angeles, CA; 2013;7(5):1167-75.

45. Pallela SRN, Narahari P. A study to find the causes of diabetic foot 
infections in a selected community. Int J Surg. 2017;4(7):2153-6.

46. Amemiya A, Noguchi H, Oe M, Sanada H, Mori T, editors. Establishment of a measurement method for in-shoe pressure and shear stress in specific regions for diabetic ulcer prevention. 2016 IEEE 38th Annual International Conference of the Engineering in Medicine and Biology Society (EMBC), United States: Aug 2016.p. 2291-94.

47. Petre M, Tokar P, Kostar D, Cavanagh PR. Revisiting the total contact cast: maximizing off-loading by wound isolation. Diabetes Care. 2005;28(4):929-30.

48. Yavuz M, Erdemir A, Botek G, Hirschman GB, Bardsley L, Davis BL. Peak plantar pressure and shear locations: relevance to diabetic patients. Diabetes Care. 2007;30(10):2643-5.

49. Sargar MPT, Pardeshi S. Smart shoe for diabtic neuropathy. Int J Adv Technol Engineer Sci. 2016;4(05):211-8.

50. Chitikeshi V, Mahajan A, Chitikeshi S, Gupta R, Schoen M, editors. An intelligent foot monitoring system for diabetic patients to prevent foot ulcerations. ASME 2006 International Mechanical Engineering Congress and Exposition; American Society of Mechanical Engineers. December 14, 2007.p. 697-702.

51. Yudovsky D, Nouvong A, Pilon L. Hyperspectral imaging in diabetic foot wound care. J Diabetes Sci Technol. 2010;4(5):1099113.

52. Singh S, Pai DR, Yuhhui C. Diabetic foot ulcer-diagnosis and management. Clin Res Foot Ankle. 2013;1(3):120-9.

53. Scire V, Leporati E, Teobaldi I, Nobili LA, Rizzo L, Piaggesi A. Effectiveness and safety of using Podikon digital silicone padding in the primary prevention of neuropathic lesions in the forefoot of diabetic patients. J Am Podiatr Med Assoc. 2009;99(1):28-34.

54. Penny HL, Webster N, Sullivan R, Spinazzola J, Green A, Faretta M. The Use of acticoat moisture control for the successful treatment of diabetic ulcers. Adv Skin Wound Care. 2009;22(10):453-6.

55. Jayashree J, SrimanNarayanalyengar NC. A Review on mobile based intelligent systems for homecare monitoring of diabetic mellitus foot ulcer. Int J Smart Home. 2016;10(8):251-62.

56. Petrofsky JS, Lawson D, Berk L, Suh H. Enhanced healing of diabetic foot ulcers using local heat and electrical stimulation for 30 min three times per week. J Diabetes. 2010;2(1):41-6.

57. Yazdanpanah L, Nasiri M, Adarvishi S. Literature review on the management of diabetic foot ulcer. World J Diabetes. 2015;6(1):3753.

58. Subashini R, Samreen A, Deepthi G, Mythili S. Detection of diabetic disorders in the lower extremities: A cost effective screening device. Biomed Res. 2014; 25(4):483-8

59. Yavuz M, Tajaddini A, Botek G, Davis BL. Temporal characteristics of plantar shear distribution: relevance to diabetic patients. J Biomech. 2008;41(3):556-9.

60. Begg L, McLaughlin P, Manning L, Vicaretti M, Fletcher J, Burns J. A novel approach to mapping load transfer from the plantar surface of the foot to the walls of the total contact cast: a proof of concept study. J Foot Ankle Res. 2012;5(1):32-7.

61. Chang CT, Liu CS, Soetanto W, Wang WC, editors. A platformbased foot pressure/shear sensor. Health Monitoring of Structural and Biological Systems: International Society for Optics and Photonics. 8 June 2018.p.1-5.

62. Huang T, Lan L, Fang X, An P, Min J, Wang F. Promises and Challenges of big data computing in health sciences. Big Data Research. 2015;2(1):2-11.

63. Deschamps K, Matricali GA, Roosen P, Nobels F, Tits J, Desloovere $\mathrm{K}$, et al. Comparison of foot segmental mobility and coupling during gait between patients with diabetes mellitus with and without neuropathy and adults without diabetes. Clin Biomech (Bristol, Avon). 2013;28(7):813-9.

64. Kalish J, Hamdan A. Management of diabetic foot problems. J Vasc Surg. 2010;51(2):476-86.

65. Tentolouris N, Voulgari C, Liatis S, Kokkinos A, Eleftheriadou I, Makrilakis K, et al. Moisture status of the skin of the feet assessed by the visual test neuropad correlates with foot ulceration in diabetes. Diabetes Care. 2010;33(5):1112-4.

66. Khanolkar M, Bain S, Stephens J. The diabetic foot. QJM. 2008;101(9):685-95.

67. Bus S. Innovations in plantar pressure and foot temperature measurements in diabetes. Diabetes Metab Res Rev. 2016;32(S1):221-6.

68. Abdul Razak AH, Zayegh A, Begg RK, Wahab Y. Foot plantar pressure measurement system: A review. Sensors. 2012;12(7):9884912.

69. Priya SK, Nithyaa A, PremKumar R. Screening of foot ulceration in diabetic neuropathy patients using flexi force sensor platform. Int $\mathrm{J}$ Sci Eng Res. 2014;5(4):87-92.

70. Liang TC, Lin JJ, Guo LY. Plantar pressure detection with fiber Bragg gratings sensing system. Sensors. 2016;16(10):1766-76.

71. Armstrong DG, Holtz-Neiderer K, Wendel C, Mohler MJ, Kimbriel HR, Lavery LA. Skin temperature monitoring reduces the risk for diabetic foot ulceration in high-risk patients. Am $\mathrm{J}$ Med 2007; 120(12):1042-6.

72. Kavitha KV, Tiwari S, Purandare VB, Khedkar S, Bhosale SS, Unnikrishnan AG. Choice of wound care in diabetic foot ulcer: A practical approach. World J Diabetes. 2014;5(4):546.

73. Milne SD, Seoudi I, Al Hamad H, Talal TK, Anoop AA, Allahverdi $\mathrm{N}$, et al. A wearable wound moisture sensor as an indicator for wound dressing change: an observational study of wound moisture and status. Int Wound J. 2016;13(6):1309-14.

74. Khalfallah K, Ayoub H, Calvet JH, Neveu X, Brunswick P, Griveau $\mathrm{S}$, et al. Noninvasive galvanic skin sensor for early diagnosis of sudomotor dysfunction: application to diabetes. IEEE Sens J. 2012;12(3):456-63.

75. Noor S, Zubair M, Ahmad J. Diabetic foot ulcer-a review on pathophysiology, classification and microbial etiology. Diabetes Metab Syndr. 2015;9(3):192-9.

76. Lavery LA, Armstrong DG. Temperature monitoring to assess, predict, and prevent diabetic foot complications. Curr Diab Rep. 2007;7(6):416-9.

77. Perrier A, Vuillerme N, Luboz V, Bucki M, Cannard F, Diot B, et al. Smart Diabetic Socks: Embedded device for diabetic foot prevention. IRBM . 2014;35(2):72-6.

78. Lin S, Ying MK, Ming TX, Ying L, Cheung WW, Fai LK, et al., editors. Monitoring diabetic patients by novel intelligent footwear system. International Conference on Computerized Healthcare (ICCH), Hong Kong, China: IEEE, 17-18 Dec. 2012.p.1-7.

79. dos Reis MdC, Soares FA, da Rocha AF, Carvalho JL, Rodrigues $\mathrm{SS}$, editors. Insole with pressure control and tissue neoformation induction systems for diabetic foot. Engineering in Medicine and Biology Society (EMBC), Annual International Conference of the IEEE; Buenos Aires; Argentina, August 31 - September 4, 2010.p. 5748-51.

80. Dabiri F, Vahdatpour A, Noshadi H, Hagopian H, Sarrafzadeh M, editors. Electronic orthotics shoe: Preventing ulceration in diabetic patients. Engineering in Medicine and Biology Society, 30th Annual International Conference of the IEEE, United States: IEEE; ;2010.p.5748-51.

81. Hobizal KB, Wukich DK. Diabetic foot infections: current concept review. J Foot Ankle. 2012;3(1):18409-10.

82. Sahana H R SSU, Pallavi Badiger, Bindu B.J, Nagendra G L, SUDHA .H. Diabetic foot neuropathy monitoring system. Int J Eng Sci. 2016;5(12): 1-6.

83. Pam Spruce LB, Sue Johnson, Debra O'Brien. Introducing HydroClean plus for wound-bed preparation: a case series. Wounds Int. 2016 7(1):26-32

84. Sadhana S. Jadhav PMMN. A Survey on wound assessment system patients of foot ulcer diabetes identification based on smartphone. IJIRCST. 2015;3(11):10904-8.

85. Chapman J, Preece S, Braunstein B, Höhne A, Nester C, Brueggemann $\mathrm{P}$, et al. Effect of rocker shoe design features on forefoot plantar pressures in people with and without diabetes. Clin Biomech (Bristol, Avon). 2013;28(6):679-85.

86. Ramana R G AR, Rambabu K, Prakash K. Simple and cost effective foot pressure detection system for diabetic patients. Int $\mathrm{J}$ Innovat Res Comput Commun Engineer. 2017;6(5):4070 -76.

87. David Jegede Ol, Ferens K, Griffith B, Podaima B. A Smart Shoe to prevent and manage diabetic foot diseases. Int'l Conf Health Informatics and Medical Systems, Nevada USA: 25 July 2015. p. $47-$ 54.

88. Park J, Kim JK, Patil SJ, Park JK, Park S, Lee DW. A Wireless pressure sensor integrated with a biodegradable polymer stent for biomedical applications. Sensors (Basel). 2016;16(6): 809-25.

89. Owings T, Apelqvist J, Stenström A, Becker M, Bus S, Kalpen A, et al. Plantar pressures in diabetic patients with foot ulcers which have remained healed. Diabet Med. 2009;26(11):1141-6.

90. Serena T, Connell H, McConnell S, Patel K, Doner B, Sabo M, et 
al. Novel multivalent wound-healing ointment provides bioburden control and moisture management: a retrospective registry data analysis. Adv Skin Wound Care. 2016;29(10):461-8.

91. Shojaiefard A, Khorgami Z, Larijani B. Independent risk factors for amputation in diabetic foot. Int J Diabetes Dev Ctries . 2008;28(2):32.

92. Mat Saad AZ, Khoo TL, Halim AS. Wound bed preparation for chronic diabetic foot ulcers. ISRN Endocrinol. 2013; 8(1): 897-903.

93. Ambegoda A, Wijesekera J, Panditharathne K, Gamage R, Mudalige O, Piyasiri M. Analysis of Severity and anatomical distribution of diabetic foot ulcers; a single unit experience. Int J Curr Multidiscip Stud. 2016;2(1): 1-10.

94. Calderini C, Cioni F, Haddoub S, Maccanelli F, Magotti MG, Tardio S. Therapeutic approach to "diabetic foot" complications. Acta Biomed. 2014;85(3):189-204

95. Lipsky BA, Berendt AR, Deery HG, Embil JM, Joseph WS, Karchmer AW, et al. Diagnosis and treatment of diabetic foot infections. Plast Reconstr Surg Glob Open. 2006;117(7S):212S-38S.

96. Hillson R. Sweating in diabetes. Pract Diabetes Int. 2017;34(4):1145.

97. Branthwaite H, Chockalingam N, Greenhalgh A. The effect of shoe toe box shape and volume on forefoot interdigital and plantar pressures in healthy females. J Foot Ankle Res. 2013;6(1):28-37.

98. Landsman A, Agnew P, Parish L, Joseph R, Galiano RD. Diabetic foot ulcers treated with becaplermin and TheraGauze, a moisturecontrolling smart dressing: a randomized, multicenter, prospective analysis. J Am Podiatr Med Assoc. 2010;100(3):155-60.

99. Sueki H, Furukawa N, Higo N, Akiyama M, Batchelor J, Iijima M. Association of verrucous skin lesions and skin ulcers on the feet in patients with diabetic neuropathy. Clin Exp Dermatol. 2004;29(3):247-53.

100. Enkhzul D, Erdenechimeg D, Amartuvshin T, Chuluunbaatar N, Enkhbaatar T. Implementation of early diagnostic device for diabetic foot using the thermal sensor. Diabetic Foot.2016; 1(4):1-5.

101. Erdenechimeg D, Enkhzul D, Munkhtamir O, Enkhbat B, editors. Wireless monitoring method for diabetic foot temperature. 19th International Conference on IEEE Advanced Communication Technology (ICACT),Bongpyeong, South Korea; 19-22 Feb. 2017.p. 15-21.

102. Lavery LA, Higgins KR, Lanctot DR, Constantinides GP, Zamorano RG, Athanasiou KA, et al. Preventing diabetic foot ulcer recurrence in high-risk patients: use of temperature monitoring as a self-assessment tool. Diabetes Care. 2007;30(1):14-20.

103. Iven G, Chekh V, Luan S, Mueen A, Soliz P, Xu W, et al., editors. Non-contact sensation screening of diabetic foot using low cost infrared sensors. IEEE 27th International Symposium on ComputerBased Medical Systems (CBMS), New York, NY, USA: IEEE; 27-29 May 2014.p. 479-80.

104. Frykberg R, Tallis A, Tierney E. Diabetic foot self examination with the Tempstat as an integral component of a comprehensive prevention program. J Diabetic Foot Compl. 2009;1(1):13-8.

105. van Netten JJ, Prijs M, van Baal JG, Liu C, van Der Heijden F, Bus SA. Diagnostic values for skin temperature assessment to detect diabetes-related foot complications. Diabetes Technol Ther. 2014;16(11):714-21.

106. Skafjeld A, Iversen MM, Holme I, Ribu L, Hvaal K, Kilhovd BK. A pilot study testing the feasibility of skin temperature monitoring to reduce recurrent foot ulcers in patients with diabetes-a randomized controlled trial. BMC Endocr Disord. 2015;15(1):55.

107. Alexiadou K, Doupis J. Management of diabetic foot ulcers. Diabetes Ther. 2012;3(1):4-12.

108. Zipfel B, Berger L. Shod versus unshod: The emergence of forefoot pathology in modern humans? Foot. 2007;17(4):205-13.

109. Lobmann R, Zemlin C, Motzkau M, Reschke K, Lehnert H. Expression of matrix metalloproteinases and growth factors in diabetic foot wounds treated with a protease absorbent dressing. J Diabetes Complications. 2006;20(5):329-35.

110. Larijani B, Hasani Ranjbar S. Overview of diabetic foot; novel treatments in diabetic foot ulcer. Daru . 2008;16(supplement 1):1-6.

111. Boulton AJ. The diabetic foot-an update. Foot Ankle Surg. 2008;14(3):120-4.

112. Uçkay I, Gariani K, Pataky Z, Lipsky BA. Diabetic foot infections: state-of-the-art. Diabetes Obes Metab. 2014;16(4):305-16.

113. Sakthivel J JV. Wireless pressure measurement and power generation using sensor. J Adv Chem. 2016;23: 5530-35.

114. Payne C, Turner D, Miller K. Determinants of plantar pressures in the diabetic foot. J Diabetes Complicat. 2002;16(4):277-83.

115. Pham H, Armstrong DG, Harvey C, Harkless LB, Giurini JM, Veves A. Screening techniques to identify people at high risk for diabetic foot ulceration: a prospective multicenter trial. Diabetes Care. 2000;23(5):606-11.

116. LaSalvia MT, Clark AT, Karchmer AW. Diabetic Foot infection. Hosp Med Clin. 2012;1(2):e185-e98.

117. Brand PW. Tenderizing the foot. Foot Ankle Int. 2003;24(6):45761.

118. Hall M, Shurr DG, Zimmerman MB, Saltzman CL. Plantar foot surface temperatures with use of insoles. Iowa Orthop J. 2004;24:72.

119. Shah J. Hyperbaric oxygen therapy. J Am Col Certif Wound Spec. 2010;2(1):9-13.

120. Bolton L. Operational definition of moist wound healing. J Wound Ostomy Continence Nurs. 2007;34(1):23-9.

121. Volmer-Thole M, Lobmann R. Neuropathy and diabetic foot syndrome. Int J Mol Sci. 2016;17(6):917-28.

122. Lavery LA, Armstrong DG, Boulton AJ. Ankle equinus deformity and its relationship to high plantar pressure in a large population with diabetes mellitus. J Am Podiatr Med Assoc. 2002;92(9):479-82.

123. Kwon OY, Mueller MJ. Walking patterns used to reduce forefoot plantar pressures in people with diabetic neuropathies. Phys Ther. 2001;81(2):828-35. 